\title{
Beyond climatic intervention: The social dimension of a biogas project in Sogwala village, Zimbabwe
}

\author{
Nyaradzo Dhliwayo ${ }^{1}$, Nelson Chanza ${ }^{2}$, Anton de Wit $^{3}$ \\ 1 Department of Geosciences, Nelson Mandela University, Port Elizabeth, South Africa \\ ORCID: 0000-0001-7568-0141 \\ 2 Department of Geography, Bindura University of Science Education, Private Bag 1020, Bindura, Zimbabwe \\ ORCID: 0000-0001-5328-5546 \\ 3 Department of Geosciences, Nelson Mandela University, Port Elizabeth, South Africa \\ ORCID: 0000-0001-7277-2630
}

\begin{abstract}
There is now considerable interest to understand how local communities experiencing climatic risks can benefit from climate change responses. As this agenda unfolds, there is need to understand the impact of climaterelated interventions from the perspective of local populations targeted by such projects. Existing assessment approaches tend to concentrate on the environmental and economic impacts of projects that minimise greenhouse gas emissions. This study assesses the social aspect of a domestic biogas project that was intended to address the twin challenges of poverty and climate change in Sogwala village, Zimbabwe. A three-tier methodological execution process was adopted, involving field reconnaissance, household survey and key informant interviews. The focus was on measuring the social dimension of the changes brought about by the project, from the experiences of participating households. With a consciousness of assessment challenges associated with community projects, social capital parameters were used to assess the project's contribution to the social wellbeing of the villagers. Overall, results show that the biogas project has the potential to facilitate social development through improved trust and social networks. Despite the contested climatic benefits associated with small-scale household biogas digesters, projects of this nature can enhance community relationships and networks, upon which other development interventions can be operationalised.
\end{abstract}

Keywords: climate change, mitigation, social capital, poverty

Highlights:

- Introducing the biogas project facilitated social development.

- Clean energy projects create opportunities for poverty alleviation.

Journal of Energy in Southern Africa 31(4): 43-56

DOI: https://dx.doi.org/10.17159/2413-3051/2020/v31i4a8924

Published by the University of Cape Town ISSN: 2413-3051

This work is licensed under a Creative Commons Attribution-ShareAlike 4.0 International Licence

https://journals.assaf.org.za/jesa

Sponsored by the Department of Science and Innovation

Corresponding author: Tel: +263 (0)772209860

email: nchanza@gmail.com 


\section{Introduction}

As the world warms up to embrace mitigation, a climate change intervention strategy defined by the Intergovernmental Panel on Climate Change (IPCC) as a package of measures to both cut sources of greenhouse gases (GHGs) and enhance their sinks (IPCC, 2014), it is pertinent to evaluate the broad impacts of mitigation projects. Not only should such efforts be concerned with minimising atmospheric GHGs, but they should also create opportunities to address the poverty situation of communities affected by climate change. The latter strand, requiring that communities experiencing climate-related disturbances be given some attention, calls for rigorous examination of the nature of changes that the people experience following mitigation projects. This suggests that climatic interventions should be challenged to give meaningful changes to the people at risk of climatic disturbances. There are notable insights about the role of renewable energy in increasing energy security (Mandelli et al., 2016; Surroop et al., 2019; Hamed and Bressler, 2019). For example, similar projects were reported in Mozambique and Tanzania (Ahlborg and Hammar, 2014), Nepal, Peru and Kenya (Yadoo and Cruickshank, 2012) and India (Palit, 2013). Similarly, in Zimbabwe, the climate mitigation agenda has seen increased appetite, largely by the development community, to embrace clean energy interventions. This has created opportunities for making energy accessible to rural communities. Given their remoteness and the general high cost of setting up conventional energy infrastructure, many rural areas in the country would have taken ages to access clean energy and to benefit from the spill-over effects associated with such projects.

However, the adoption of these projects (Boers, 2012; Mwirigi et al., 2014), including their intended environmental and socio-economic benefits in subSaharan Africa, have received mixed reviews (Arthur et al., 2011; Landi et al., 2013; Gabisa and Gheewala 2019). As such, there is still controversy in the anticipated climatic benefits of small-scale household biogas digesters in many places where such projects are being carried out (Bruun et al., 2014; Somanathan and Bluffstone, 2015). This dispute tends to mask the social benefits that accrue to communities adopting biogas projects. Conscious of the mitigation contribution debate associated with such projects, this study examines whether the social networks created from community interactions during the course of the biogas projects can create development opportunities beyond the projected climatic benefits. This paper assesses the social dimension of the changes brought about by a domestic biogas project implemented in the rural village of Sogwala in Zimbabwe.
First, the paper gives an overview of the donordriven household biogas project in Sogwala. The contemporary scholarly insights emerging from the diffusion and effectiveness of biogas projects within the climate change discourse are also given. Also highlighted are the assessment gaps and complexities associated with twinning the complex topics of climate change and poverty in terms of social sustainability of development projects. A social capital theoretical framework is used to situate the methodology that the study uses to assess the social facet of the biogas project. Within this framework, results based on the social impact indicators of the project from the perspective of villagers interviewed are presented. The discussion is also woven around the project's contribution to community relationships and networks.

\section{Overview of the biogas project in Sogwala village}

Sogwala is a dryland rural village located in Gweru Rural District of Midlands Province in Zimbabwe. It is located about 80 kilometres west of Gweru, the city which is the capital of Midlands Province (see Figure 1). The area falls in agro-ecological region 4, which is associated with a dry climate. In Zimbabwe, climatic suitability for farming largely declines from region 1 to region 5 (Mugandani et al. 2012). The area experiences low rainfall $(450-650 \mathrm{~mm}$ mean annual rainfall), which makes crop farming a challenge even in normal rainfall seasons. However, the dry ecological regions are known to be more favourable for livestock production than the wetter ones, and this is the main agricultural activity, and so the main source of livelihood, of the villagers. The perennial flow of Vungu River supports horticulture, which often supplements the income of some households, who market their produce as far as Gweru. Earlier studies indicate an average cattle herd size of 7.1 per household (Christensen and Zindi, 1991) but this is believed to have declined largely, because of climate change (Tavirimirwa et al., 2013; Masama, 2016). Threats to livestock production mainly emanate from climate change-related high temperatures and declining rainfall that deplete grazing pastures and water sources (Chanza et al., 2018). Notwithstanding these challenges, Boers (2012) reported high potential for domestic biogas projects.

In Zimbabwe's rural areas, wood fuel is the primary source of domestic energy, and is used for cooking, lighting and heating by over $90 \%$ of rural people. With increased demand for farming land and irregular electricity supply in urban areas, this situation exerts pressure on forestry resources (Boers, 2012; Marambanyika et al., 2016). The population density is 15.59 per $\mathrm{km}^{2}$ and smallholder peas- 


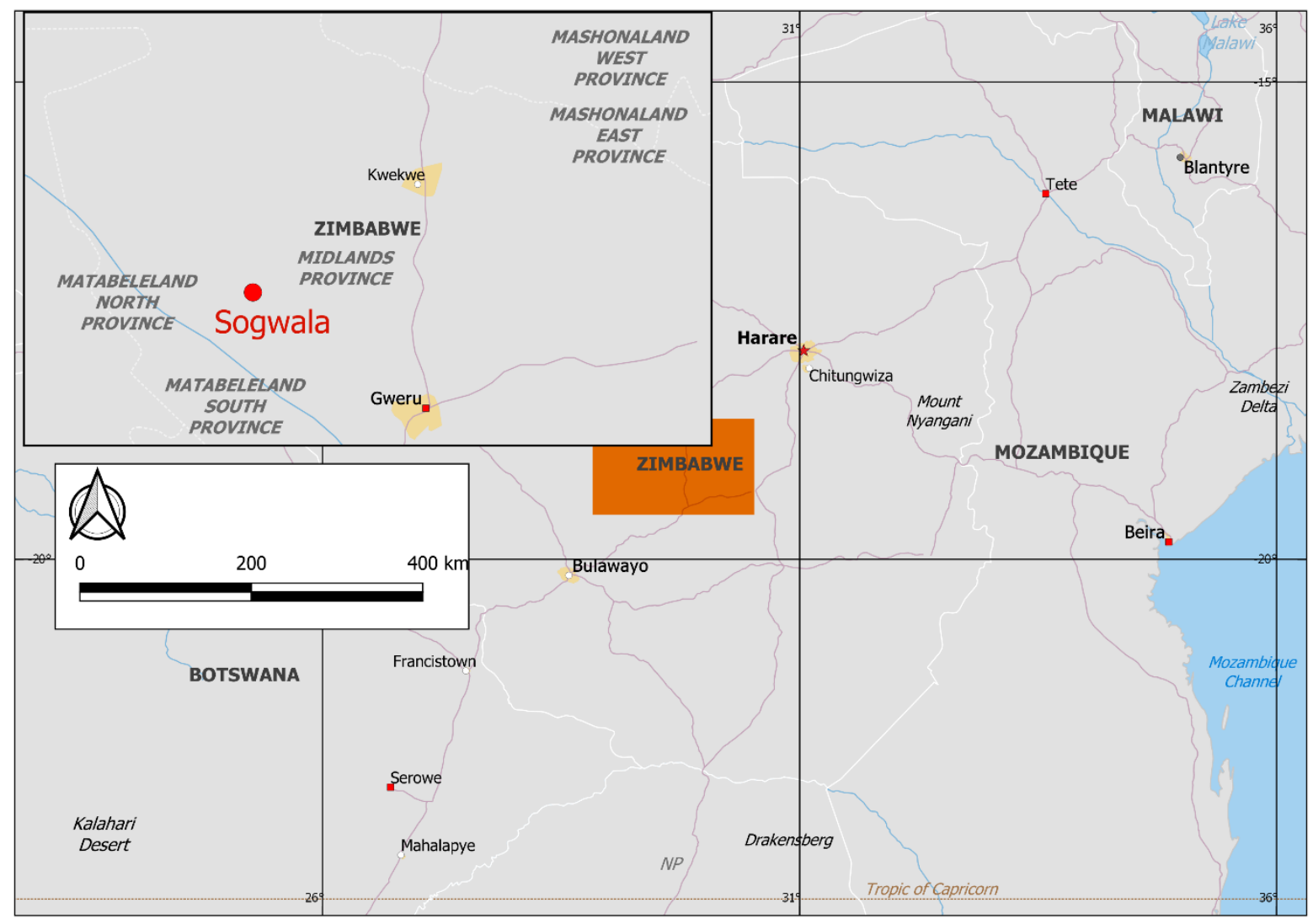

Figure 1: Location of the study area.

ant families occupy state land (ZimStat, 2013). Chanza et al. (2018) report that the livelihoods of rural populations in Zimbabwe are already showing signs of vulnerability to climatic forces. This unsustainable situation triggered the government, with support from development partners, to embark on the development of sustainable energy projects targeting rural communities. Sogwala Village in Dufuya Ward was among the communities targeted for piloting the biogas project, hence the choice of this case study.

In Gweru Rural District, about 85\% of the households use wood for cooking and only $9 \%$ have access to electricity. The literacy level is $95 \%$ (96\% for males, $94 \%$ for females) (Zimstat, 2013). Due to growing rural poverty, the villages are supported by development programmes coming largely from donors. The development focus of these partners covers sustainable livelihood programmes, with an assortment of community support projects in the areas of energy, health and agriculture. The biogas project was implemented by Heifer International Zimbabwe (HIZ) in 2003 as a sustainable energy and conservation branch of a much larger integrated wetland protection, management and utilisation project. It involved installing low-cost bio-digesters that harness animal waste to produce biogas for household cooking, heating and lighting. The support given by HIZ was broad - involving constructing livestock shelters, poultry pans, and promoting improved cook stoves, dairy programmes, tree-planting, environmental projects and rotational grazing. Prior to this project, the villagers had been using a mix of energy sources, but a baseline study conducted by HIZ revealed that fuelwood was the main source of energy for cooking. Given that participation in the project was free, almost all the villagers had biogas plants installed at their homesteads. Notwithstanding the operational challenges reported by Boers (2012), the support given by the donors has helped the beneficiaries to maintain the bio-digesters. While the contribution of such projects to the relief in pressure in forestry resources has been studied elsewhere (Reed et al., 2015), not much is known about the social aspect of the biogas projects in Zimbabwe.

\section{Literature review}

\subsection{Evaluation of biogas projects}

Climate change continues to push for significant attention in the energy sector, which is responsible for 35\% of anthropogenic GHG emissions (IPCC, 2014). Within this drive, the biogas sector has attracted critical thoughts as a clean energy source (Cuéllar and Webber, 2008; Pathak et al., 2009, Cornejo and Wilkie, 2010; Arthur et al., 2011; Mo- 
han et al., 2012; Boulamanti et al., 2013; Bruun, 2014; Somanathan and Bluffstone, 2015). Notwithstanding this growing interest, the adoption of biogas projects in developing countries appears to have some challenges (Bruun et al., 2014; Mwirigi et al., 2014; Tigabu et al., 2015; Bekchanov et al., 2019). Similarly, evaluation of implemented projects has not reported much on the social aspect. Bruun et al. (2014) and Pilloni et al. (2020) indicate several benefits of small-scale biogas production on farms, including savings on firewood, and health gains from reduced soot and odours from emissions. However, Bruun et al. (2014) warn that the characteristic poor management of biogas digesters and distribution system of the gas results in methane leakages that compromise the mitigation advantages - methane gas is 25 times more lethal as a GHG than carbon dioxide.

A limited but growing number of studies focus on the adoption and diffusion of biogas projects in developing countries. In rural Pakistan, a recent study conducted by Yasmin and Grandmann (2019) revealed that wealthy farmers are more likely to successfully adopt biogas technology. The authors identified poor operational methods, lack of maintenance and training facilities as the main reasons for the functional failure and discontinuation of biogas plants. In Israel, Pilloni et al. (2020) observed that patriarchy and financial limitations represented barriers to biogas adoption and diffusion, while knowledge dissemination, and financial and policymaker support were seen as critical drivers for biogas technology uptake. Bekchanov et al. (2019) explained reasons for slow adoption in biogas technology despite promising potential in energy security and climate change mitigation. The reasons they cited were mainly knowledge and technology gaps. Their comments resonate with earlier insights by Cornejo and Wilkie (2010) and Mshandete and Parawira (2009), who also pointed out technology filtration challenges in developing countries.

Indraprahasta and Alamsyah (2014) highlighted development opportunities associated with implementing biogas projects in rural areas. They pointed out that, despite several decades of developments in the sector, very few studies have been conducted to understand how biogas interventions influence rural development. In their report on their study, conducted in Indonesia, the authors reveal that benefits were not confined to the infrastructural, economic and environmental aspects, but also covered the human-cultural dimension of the impacts. A review of Rwanda's National Domestic Biogas Programme by Landi et al. (2013) showed limited success, largely owing to lack of familiarity with biogas technology and minimal institutional capacity. The available biogas projects doc- umented concentrate mostly on technological and policy aspects (Mshandete and Parawira, 2009; Landi et al., 2013; Tigabu et al., 2015) and human capacity gaps (Cornejo and Wilkie, 2010), with limited attention to the social impacts reported by beneficiaries of such projects. Mshandete and Parawira (2009) reviewed biogas technology research in sub-Saharan Africa, and noted limited research on the topic. Later, Mwirigi et al. (2014) acknowledged growing research on the diffusion and accessibility of biogas technology, but identified several socioeconomic factors that hamper widespread adoption of small-scale biogas digesters in the region. Amigun et al. (2012) suggested that biogas provides an opportunity to improve quality of life of communities in Africa, as interventions in this sector can promote adequate, affordable, efficient and reliable high-quality energy services. Similarly, Yasmin and Grandmann (2019) showed that biogas adoption significantly impacts on household and village incomes and minimises fuelwood expenditures and collection time. Overall, the researchers cited here corroborate the view that biogas technology is capable of unlocking development opportunities and contributing towards poverty alleviation. However, the question of the social sustainability of such projects, particularly what happens to the community following the withdrawal of technical support by development partners, has not received intensive scrutiny in most assessment exercises of biogas projects.

\subsection{A social dimension focus}

The theoretical focus used to examine the social impacts of the biogas project revolves around the concept of social capital. This dimension acknowledges the social resource base and shared values of society and its constituent groups and networks (Lin et al., 2001). As a concept, social capital is understood as the glue that holds society together (Brunckhorst, 2002; Grootaert and van Bastelaer, 2002; Blanco and Campbell, 2006; Field 2008). Brunckhorst (2002) refers to it as the state of social relations amongst people in groups or communities, while Grootaert and van Bastelaer (2002) describe social capital in terms of the institutions, relationships, attitudes and values that govern such interactions. The most popular definition comes from Putnam (1996:66), who equates social capital to 'the features of social life - networks, norms and trust - that enable participants to act together more effectively to pursue shared objectives'. Social capital is, therefore, a resource for collective action, in the sense that it can be mobilised by communities in order to collectively achieve a wide range of benefits that are related to their livelihoods (Lin et al., 2001; Engbersen et al., 2006). Scholars assessing social capital mostly focus on the question of inter- 
connectedness of social groups and people (Malan, 2004; Gates and Lee, 2005). From Putnam's definition of social capital, it can be deduced that networks include a wide variety of formal and informal social groups and communities with an unlimited number of functions. Networks of friends and families are obvious examples, as are clubs, associations and working groups. The research community has treated such networks as structural social capital, highlighting the connectedness of people as an important element in social capital. Structural social capital can further be divided into bonding, bridging and linking capital (Coleman, 1988). In essence, the more social groups people are involved in, the stronger social capital is (Grootaert and van Bastelaer, 2002; Field, 2008).

For purposes of developing the measurement tool of social capital, it is vital to understand and define its components. Bonding capital, for instance, enables cohesive relationships and cooperation within a single social group or society, while bridging capital facilitates cohesive relationships and cooperation between different social groups (Putnam, 2000). Linking capital enables cooperation between communities or groups and external authorities that may include governmental departments and non-governmental organisations (NGOs) Grootaert and van Bastelaer, 2002). Norms in Putnam's (1996) definition - also known as cognitive social capital (Grootaert and van Bastelaer, 2002) - underlie the functionality of networks (Uphoff and Wijayaratna, 2000) and therefore refer to the ingredients which facilitate cohesion and cooperation within and between communities and groups (Fukuyama, 2001). Examples include so-called 'traditional values', which, according to Fukuyama (2001), refers to elements such as honesty, reciprocity and simple and timeous honouring of commitments. Reciprocity is, however, sometimes isolated as a key norm in social capital. It entails mutually supportive behaviour being expected from members of a social group or community through embedded reciprocal relationships embedded (Putnam, 2000). The same can be said for the issue of trust, which, when it is evident amongst members of a community, is an essential and enabling factor when cooperation is at stake (Pretty, 2002). The present study uses these social capital elements to understand the change in community relationships, networks and interactions resulting from the opportunities created through participating in the biogas project.

\section{Methodology}

From the theoretical analysis of social capital presented, the study isolated three social indicator themes and their specific indicators as: structural (social group membership), cognitive (trust), and social capital outcomes (cohesion, cooperation and empowerment). This selection guides the subsequent development of the research protocol shown in Figure 2. A three-tier methodological execution process was adopted, involving field reconnaissance, household survey and key informant interviews. The first stage involved a preliminary field assessment to establish rapport with community gatekeepers (i.e., village head, headman and councillor), to identify project officials from HIZ and to choose a field assistant familiar with the village. The HIZ provided a list of the 301 households who participated in the biogas project. The second stage constituted interviews with selected heads of households. Interviews were administered to selected households with the help of the field assistant, who understood the cultural formalities and the location of the households. The last stage selected key informants in order to understand their perceptions of the potential to enhance community development initiatives from the strengthened relationships and networks.

Adopting a systematic random sampling technique, the study targeted every third household after assigning random numbers to the 301 households. As such, 100 households participated in the research. The head of each household, or the one that would give reliable information about the household's experience with the biogas project, responded to the interview. There were 68 female and 32 male respondents. Participants' ages ranged from 31 to 65 years. Questions encouraged the respondents to compare their experiences with and without the biogas project situation, based on the social indicator themes. Each social capital element was measured from the specific indicators as shown in Table 1. Thus, the questions solicited participants' ratings of group membership, trust, cohesion, cooperation and empowerment, and if they felt these could be maintained following withdrawal of external support. Key informant interviews were intended to give greater understanding of the project operation. These informants were drawn from project officials, government officers and other opinion leaders in the area. Themes were generated from the qualitative data in line with the social capital indicators specified. The study assumed that the influence of other social groups created by other projects was minimal. The interview questions specified that the respondents were to report on the situation before and after the biogas project. Respondents were also probed to make sure that they gave information related to the biogas project. 


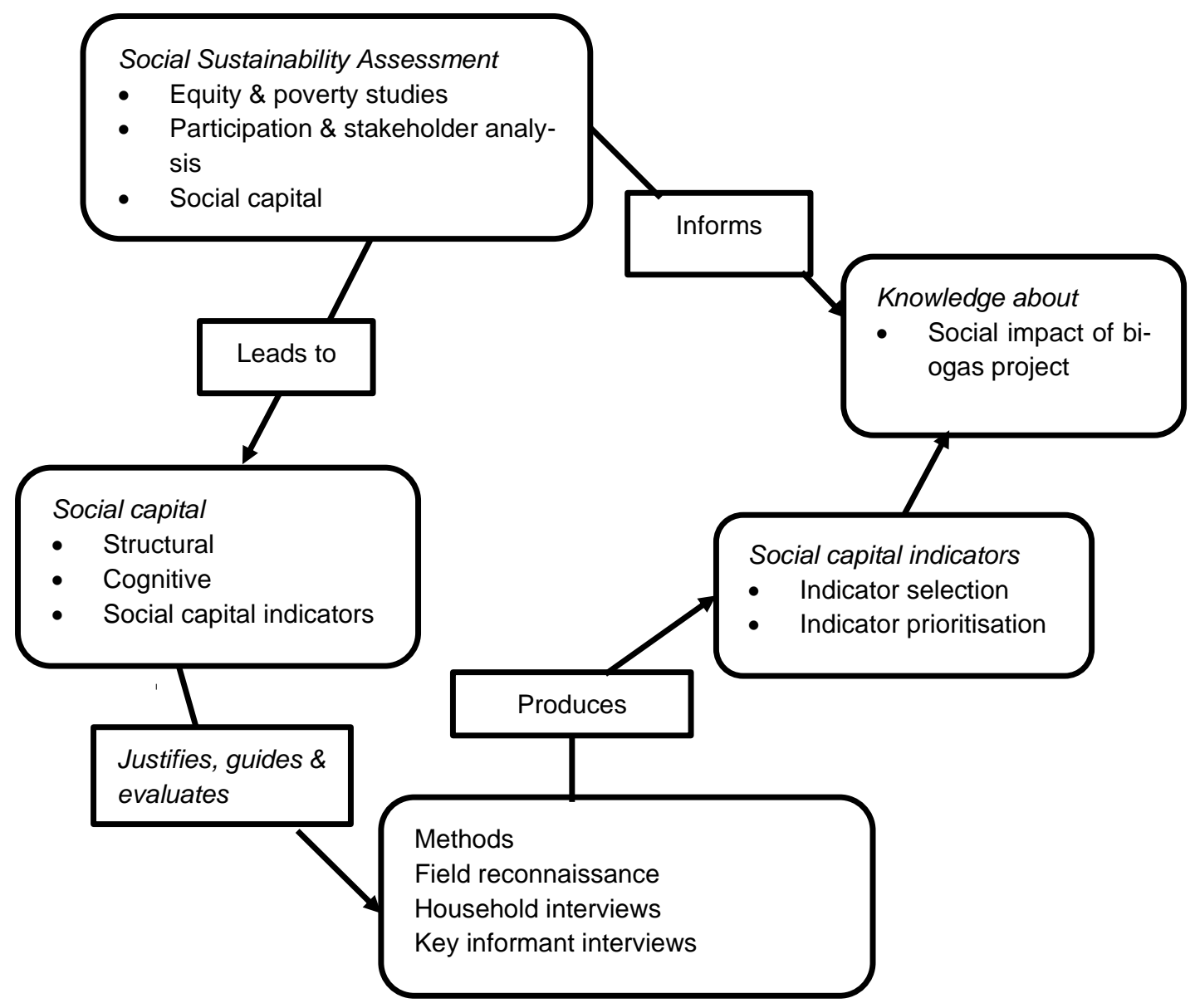

Figure 2: Procedure for determining social capital indicators.

Table 1: How the biogas project influenced social capital

\begin{tabular}{lll}
\hline $\begin{array}{c}\text { Social capital } \\
\text { element }\end{array}$ & Social capital indicator & \multicolumn{1}{c}{ Description } \\
\hline Structural & Social group membership & $\begin{array}{l}\text { Increased social group membership within the village } \\
\text { Improved interaction between members of social } \\
\text { groups within the village and with people outside the } \\
\text { village }\end{array}$ \\
\hline Cognitive & Trust & $\begin{array}{l}\text { Improved trust among community members } \\
\text { Improved trust between villagers and their community } \\
\text { leaders and government officials, external organisations } \\
\text { (NGOs) } \\
\text { Increased general willingness of people in the village to } \\
\text { support projects that will benefit the community at } \\
\text { large. }\end{array}$ \\
\hline Outcomes & Cohesion & $\begin{array}{l}\text { Brought a new interconnectedness (ukubumbana) be- } \\
\text { tween people in the village } \\
\end{array}$ \\
& Cooperation & $\begin{array}{l}\text { Replaced disunity and self-centeredness between com- } \\
\text { munity members } \\
\text { Community gained power to make important decision } \\
\text { that could change the total course of their lives. }\end{array}$ \\
& Empowerment &
\end{tabular}




\section{Results}

The evidence of how the domestic biogas project influenced social capital is described in Table 1. A description of the changes in specific indicators is given in detail in the form of social groups, trust and project outcomes.

\subsection{Growth and strengthening of social groupings}

The number of social groups that households in Sogwala belonged to (within the village) before biogas production contrasted with the situation thereafter, as shown in Table $2 .{ }^{1}$ Before the project, households belonged to an average of 1.78 groups with a membership of $87 \%$ of households falling in the range of between one and three groups. The membership situation after biogas intervention changed considerably. Social group membership of $68 \%$ of all households shifted to a concentration between three and five groups, with households belonging to 3.61 groups on average. As such, $62 \%$ of the respondents perceived that biogas production in their village contributed to the increase in their social group memberships. The villagers became acutely aware of the advantages of biogas compared to the other sources of energy that they relied on before. In view of the health and sanitation benefits of using biogas energy, the villagers were encouraged to join existing groups such as local health (sanitation) and school committees, to share with others how such benefits have impacted on them. Upon realisation of the project benefits, those who were slow to adopt the project later understood the significance of seriously joining the lead groups to fully integrate biogas into their energy sources mix. Specifically, school development committees served as a platform for villagers to share information about the project.

Table 2: Social group membership by households before and after biogas project

\begin{tabular}{ccc}
$\begin{array}{c}\text { Number of } \\
\text { social } \\
\text { groups }\end{array}$ & $\begin{array}{c}\text { Social group } \\
\text { membership be- } \\
\text { fore project (\%) }\end{array}$ & $\begin{array}{c}\text { Social group } \\
\text { membership af- } \\
\text { ter project (\%) }\end{array}$ \\
\hline 0 & 9 & 9 \\
1 & 34 & 7 \\
2 & 31 & 4 \\
3 & 22 & 14 \\
4 & 4 & 38 \\
5 & 0 & 16 \\
6 & 0 & 12 \\
\hline Total & 100 & 100 \\
\hline Average & 1.78 & 3.61 \\
number & &
\end{tabular}

In the interest of boosting land productivity, the villagers observed that the advantages of adopting the biogas project went beyond clean energy access. It was reported that the by-product (sludge) released from the bio-digester can be used as farm manure, which they apply in the fields to enhance food production. Through this, villagers were able to generate income from the sale of surplus food (mainly vegetables). Subsequently, many villagers became members of the local finance or credit group which helped in household financial management issues. The enhanced participation in farming also led village members to form and join new groups. These included the local food garden cooperative as a platform to gain and share information and experience about vegetable gardening and crop and animal farming. This explains the increase in the average number of social group membership from 1.78 to 3.61 per household membership as read in Table 2.

The HIZ organisation introduced essential training and capacity building based on in-field project management. Apart from biogas-related aspects (construction, maintenance and monitoring), the training also included generic tools such as planning, implementing, monitoring and reviewing projects, as well as aspects of communication and motivation of project members and beneficiaries. The idea behind training and capacity building was not limited to the demands of the biogas project, but extended to building community capacity that would eventually conceive and develop potential projects in the future. Due to the perceived success of the biogas project in their village, the training and capacity building sessions were well subscribed to and later, in the form of various related groups, became a key part of community social life. Respondents (95\%) also indicated that the sense of self-sufficiency brought by the project also cultivated a sense of self-worth amongst the participants. This led to increased social group membership in the village through people's willingness to interact and share experiences with others.

Due to the new developments and improved interaction within the village, the frequency of interaction between the most important social groups with groups outside the village increased. Slightly more than half of the respondents (54\%) indicated that the most important group that they belonged to would meet frequently with groups outside their village. About $63 \%$ of the respondents confirmed that the biogas project facilitated their frequent interaction with social groups within the village and with groups and people from neighbouring villages. A small share of the respondents (8\%) also felt that individuals within the village generally became more aware of the fact that they share certain information, such as the demand for clean energy and 
outside markets. As people from other villages came to the village to trade for vegetables or fertiliser, this common bond, according to the respondents, contributed to a sense of unity between villagers and those from other villages.

\subsection{Building of trust}

In the face of rural socio-economic adversity, the project brought about new linkages (ukubumbana). In the predominant Ndebele local language, $u k u$ bumbana is the word used in the village to describe a process of building interaction between two or more people or groups. This is the result of a closer cooperation between community members that was necessitated by the demands of the biogas project and, consequently, the development of a better understanding that most villagers (73\%) share common challenges. Respondents also revealed that the word ukubumbana is strongly related to the issue of trust, which suggests that this essential element of social capital has grown through the increased interaction of people.

Notably, the trust between community members and their community leaders (traditional leadership) and NGOs is a much considered aspect of relationships. It was clear that trust seemed to be a considerable community asset as far as cognitive social capital is concerned. Most respondents (75\%) said that the traditional leadership of Sogwala had always shown real and honest concern for the villagers' welfare. Regarding the development partners, HIZ as the biogas project implementing agency and other players, the respondents indicated that they trusted them to a very great $(52 \%)$ and a great (35\%) extent. They generally agreed that these organisations deliver on their promises. The idea of a promise (isethembiso) is significant in this case, since a commitment from someone or an organisation to do something is automatically viewed in the local cultural context as a promise. If such a commitment is followed by nondelivery for whatever reason, reciprocity (ukubambamisana) is likely to be compromised at the expense of trust between two parties. It is evident from Figure 3 where these findings are presented.

A clear switch took place considering the question of trust in the community and the fact that the statement from the community 'people could be trusted after the introduction of biogas' has gained ground amongst the respondents by a considerable $71 \%$. The link between this increase and biogas production sought by the study was discovered in the unanimous response that previous disunity and self-centredness between community members caused by competition over scarce livelihood opportunities had been minimised. This was confirmed by $74 \%$ of the participants. A more united village community, according to the respondents and the traditional leadership, was brought about by the various utilities of biogas and the resulting communal sense of self-sufficiency.

Results concerning the willingness of people to support new projects that would benefit the community, but not necessarily the individual, reflected project outcomes that surround the question of trust. The motivation for this, from $95 \%$ of the respondents, involved the sense of self-sufficiency, self-worth and subsequent unity in the community brought about by biogas and its utilities. As an actual demonstration of their benevolence in this case, some of these respondents (96\%) specifically referred to the so-called 'Pass on the gift' (dhlulisa isipho) project which followed the introduction of biogas in the area. As an initiative of HIZ and the traditional leadership of the village, 'Pass on the gift' involves village members sharing some of their livestock's offspring with less fortunate people. This is done to extend a network of hope, dignity and selfreliance within the community.

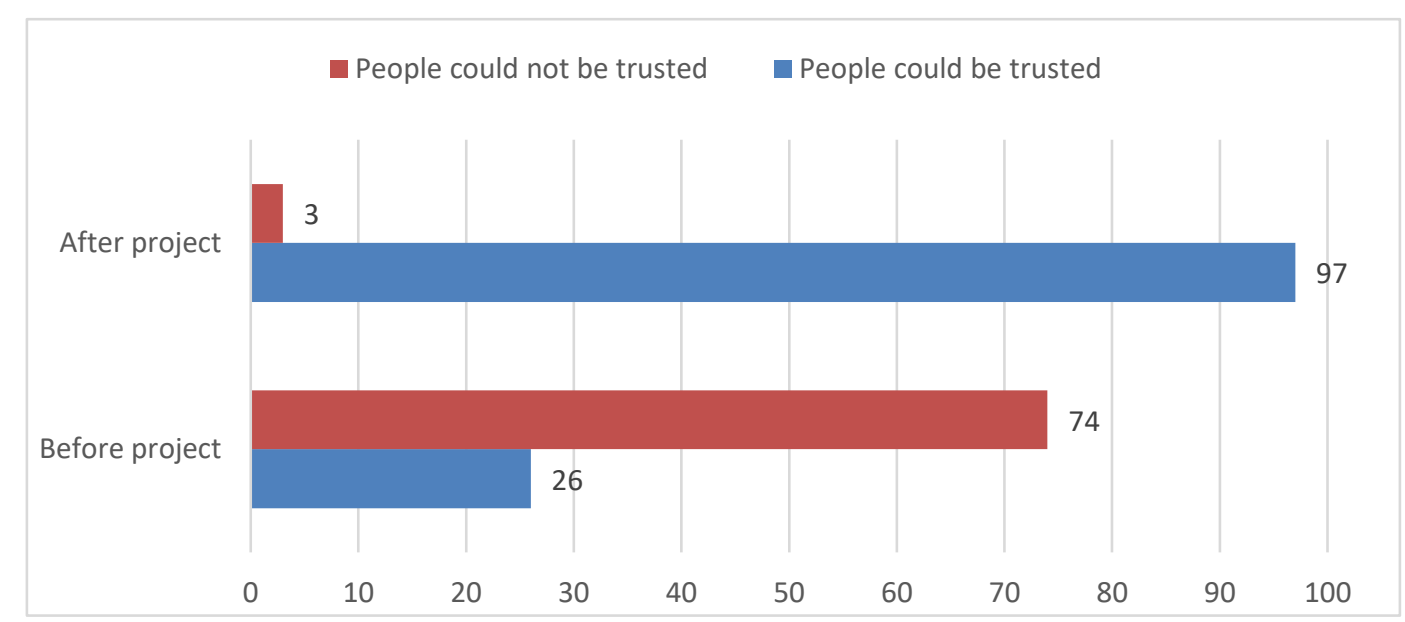

Figure 3: Respondents' views on leadership trust before and after the project (\%). 


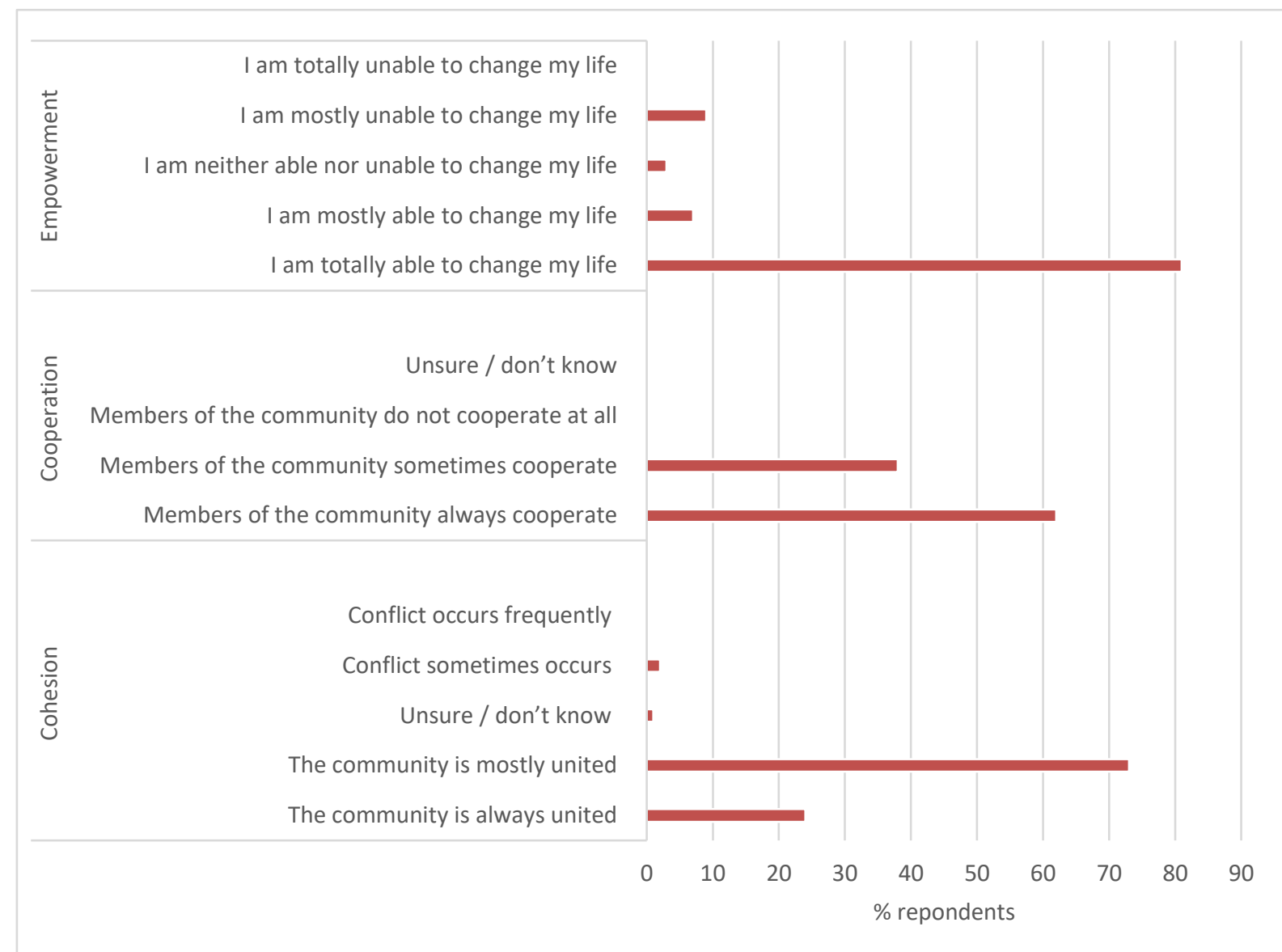

Figure 4: Respondents' views on the social outcomes of the biogas project.

\subsection{Project outcomes}

The combination of trust and community groups precipitated into the realisation of project outcomes as villagers developed an interest in working together and sharing project experiences. Accordingly, there was evidence that social capital manifests in the form of household cohesion, cooperation in project activities and other livelihood practices, and community empowerment. The three considered variables (cohesion, cooperation and empowerment) are almost predictable, especially if the results on the possibility of financial assistance, trust and willingness of people to support a community project are considered (see Figure 4).

The notion of improved cohesion was used by respondents to explain why they would support a development project for the benefit of the wider community. Two reasons were provided to explain the development of social unity. First, that it resulted from the new interconnectedness (ukubumbana) between people that developed from good cooperation between community members. The same kind of motivation was also provided by most respondents when they explained their view regarding the possibility of financial assistance from people outside the immediate family circles. Second, that social unity replaced disunity and self- centredness between community members where opportunities created by the biogas project enabled them to have close interaction. When asked to express their view about social unity in the community, a large share of the respondents revealed that the community is mostly united $(71 \%)$ or always united (24\%). There were few respondents $(2 \%)$ worried about the possibility of conflicts in their interactions in community projects.

As far as cooperation is concerned, favourable responses were advanced, with $62 \%$ of the respondents indicating that members of the community always cooperate and 38\% indicating that they sometimes cooperate. Almost two thirds of respondents indicated that motivations for cooperation emerged from the various incentives and utilities associated with biogas production in the village. Thus, what spurred people to cooperate (whether in the different contexts of the various social groups in the village or to meet the demands of the actual biogas project) is based on the benefits that they get out of the biogas project, such as employment for some, better food security, sustainable energy, cleaner and more sanitary conditions around dwellings of the village, among other realisations. This view was confirmed by HIZ as well as the traditional leadership of the village. 
The question of empowerment assessed the degree to which people have control over issues that may influence the course of their lives. Most of the respondents $(81 \%)$ indicated that they had been totally empowered to change their lives. From the respondents' revelations, this level of empowerment mainly resulted from an increasing sense of selfsufficiency brought about by biogas energy and selfworth compared to the hardships they experienced before the project. A small portion of respondents (9\%), however, stated that they did not consider themselves empowered for personal reasons, because they still lacked confidence in themselves to make important decisions that could change their lives.

\section{Discussion}

The introduction of biogas production in Sogwala presented the people with an opportunity to access clean energy, increase agricultural production and enhance their livelihoods against a backdrop of poverty and climatic disturbances. The results presented in this paper showed that the villagers' situation has improved following the project. Through their participation in the project, villagers were able to interact, form groups, build teamwork, cement relationships, build trust, and develop knowledge and share experiences and skills related to their survival in the community. This means that the benefits of the biogas project went beyond environmental objectives to include socio-economic gains largely reflected in health and sanitation, agricultural productivity, income-generation, credit schemes and community empowerment. These benefits give pointers to the development of social capital at the village level. Similarly, Bhuiyan (2011) and Muller and Coetzee (2012) recognised that strong social capital holds numerous potential benefits via community development, which relies heavily on collective action and cooperation. Networks, at the level of business corporations, contribute significantly to information and knowledge exchange and ultimately to productivity and profit (Lin et al., 2001). Thus, the findings of this study resonate with the views of Putnam (2000), Foster et al. (2015) and Johnson (2016) about how strong social capital is at the level of individuals, through networks and various social ties. Pilloni et al. (2020) confirmed that the adoption of biogas technology incorporated learning and changing behaviours such as skill development, competencies, social practices and new social roles among community members.

The benefits of biogas project assessed in this paper seem to be evident at project level. Given this seemingly limited spatial impact, there is a tendency to ignore these benefits in development discourse. For example, Tol (2005) did not account for localised climatic benefits of such projects as he argued that the benefits of mitigation are only global. The present study suggests that the benefits of mitigation projects involving biogas energy are both immediate and long term. Regarding the former case, villagers adopting clean energy projects can directly benefit through social capital platforms, which potentially create opportunities for collective action in community development initiatives. In the latter case, the cumulative environmental benefits of switching to clean energy has obvious benefits in cutting carbon emissions, albeit at a small scale. However, the contribution of these small-scale projects in climatic stabilisation remains contested (Bruun, 2014). Notwithstanding this debate, the marginalisation of the limited mitigation contribution may scare away climatic funding from communities at risk of climatic perturbations and consequently ignore development support to vulnerable communities.

However, to report that the project in discussion has significantly enhanced social capital in the community would be an overgeneralisation. Although there are indications that the biogas project could be sustained - since most households have livestock, and animal waste that is used as raw material is readily available, coupled with the basic technical skills and capacity to maintain and service the biogas digesters - it can be argued that sustaining the project may not necessarily guarantee persistence of social capital gains. There are other factors not assessed by the study (such as politics and drought), which could erode both the direct project benefits and social capital. It is also crucial to point out that the said benefits do not evenly accrue to all the village members. The issue of equity in the distribution of project benefits was not assessed in this study and this indicator could give a different picture of social development outcomes. As previously discussed, the strength of social capital is not only a factor of the number of social groups that people belong to, but is determined by how well such groups cooperate with other groups (within and outside communities) and importantly, of course, by the state of existing cognitive social capital (trust in particular). Social capital is, therefore, a complex and highly integrated phenomenon. Much has been written about the value and positive outcomes of strong social capital which, according to Blanco and Campbell (2006), can be observed at all scales. For example, the strength of social capital is an important predictor of long-term development at the national level (Muller and Coetzee, 2012), while the role of strong social capital is described to have an equally positive effect on local economic development via more adequate and efficient performance of public agencies (Dale and Newman, 2010; Foster et al., 2015). 
Despite the lack of comparability of the assessment framework used in this study, it is clear that the case adoption of the social capital framework has hinted at the predominant factors that underpin the success of climatic interventions in remote rural communities. As villagers establish and strengthen social networks, they create a platform for the success of development interventions. Development agencies from government and civil society can easily use such platforms as launch pads for project design, implementation and management. External development agencies involved in environmental or climate management projects, for example, can easily harness such community networks to disseminate information and to give incentives for responsible environmental behaviour, or give sanctions on environmental insensitive practices in such rural settings. As Chanza et al. (2018) warned, climatic interventions that fail to address the development needs of people are treated with suspicion and could be a driver of adaptation failure. Similarly, Gates and Lee (2005) stated that the question of social sustainability revolves around the prioritisation of basic needs or the improvement of human wellbeing. Such a contribution, in our view, is intended to inform practical and policy interventions to guarantee the sustainability of climatic projects. The findings confirm existing theories about the social capital dimension of social sustainability. The findings of this study advance the thoughts of Adger (2003) that social capital and climate change can positively be related where projects recognise the collective action and networks of local communities. This observation is critical in addressing the poverty implications of climate change that were reported by Hertel et al. (2010).

\section{Conclusion}

An apparent link between a biogas project and building social capital has been shown in this study. It can be said that the introduction of the biogas project generally facilitated the social capital dimension of social development. The three social capital components discussed in this research, namely, structural social capital (groups and networks), cognitive social capital (trust), and social capital outcomes (cohesion, cooperation and empowerment), are useful in giving pointers to the assessment of the social aspect of community projects. Adopting the social capital framework is critical, because it identifies groups and networks and the utility that flows from this, which is key to determining continuity in project benefits that accrue to community. This study has important implications for understanding the potential that clean energy projects can bring to communities that are characterised by energy poverty and whose poverty situation can be worsened by climate change. Essentially, sustainable climatic interventions in the form of clean energy projects that prioritise the basic needs of the community are likely to succeed, as people see them as opportunities to evade poverty. In rural communities that are vulnerable to climate change, it is advised to weave climatic interventions around the development needs of the people, in order to guarantee their sustainability. Put firmly, the centrality of poverty alleviation should be the hallmark of climate interventions in rural communities trapped under non-climatic drivers of vulnerability, a situation which characterises many African communities.

\section{Note}

This study considers social group membership as relating to voluntary involvement in community groups that are perceived to address the development needs of the villagers through information exchanges and skills sharing. A $\%$ value was determined by determining the number of respondents reporting their involvement in number of groups as a proportion of the total.

\section{Author contributions}

Nyaradzo Dhliwayo developed the research idea and was responsible for data collection and analysis. Nelson Chanza developed the paper outline, reviewed literature and presented the discussion. Anton de Wit synthesised the authors' inputs and reviewed the final paper.

\section{References}

Adger, W.N. 2003. Social capital, collective action, and adaptation to climate change. Economic Geography 79 (4): 387 404. https://doi.org/10.1111/j.1944-8287.2003.tb00220.x

Ahlborg, H. and Hammar, L. 2014. Drivers and barriers to rural electrification in Tanzania and Mozambique - Gridextension, off-grid, and renewable energy technologies. Renewable Energy 61: 117-124. https://doi.org/10.1016/j.renene.2012.09.057

Amigun, B., Parawira, W., Musango, J.K., Aboyade, A.O. and Badmos, A.S. 2012. Anaerobic biogas generation for rural area energy provision in Africa. In, Biogas, Kumar, S. (ed) IntechOpen, 35-62. https://doi.org/10.5772/32630

Arthur, R., Baidoo, M.F., Antwi, E. 2011. Biogas as a potential renewable energy source: A Ghanaian case study. Renewable Energy 36 (5): 1510-1516. https://doi.org/10.1016/j.renene.2010.11.012 
Bekchanov, M., Mondal, M.A.H., de Alwis, A. and Mirzabaev, A. 2019. Why adoption is slow despite promising potential of biogas technology for improving energy security and mitigating climate change in Sri Lanka? Renewable and Sustainable Energy Reviews 105: 378-390. https://doi.org/10.1016/j.rser.2019.02.010

Bhuiyan, S.H. 2011. Social capital and community development: An analysis of two cases from India and Bangladesh. Journal of Asian and African Studies 46 (6): 533-545. https://doi.org/10.1177/0021909611401511

Blanco, H. and Campbell, T. 2006. Social capital of cities: Emerging networks of horizontal assistance. Technology in Society 28 (1-2): 169-181. https://doi.org/10.1016/j.techsoc.2005.10.002

Boers, W. 2012. Feasibility of a national domestic biogas programme in Zimbabwe. SNV and Humanist Institute for Cooperation with Developing Countries, Harare, Zimbabwe.

Boulamanti, A., Maglio, S.D., Giuntoli, J. and Agostini, A. 2013. Influence of different practices on biogas sustainability. Biomass and Bioenergy 53: 149-161. https://doi.org/10.1016/j.biombioe.2013.02.020

Brunckhorst, D.J. 2002. Institutions to sustain ecological and social systems. Ecological Management and Restoration, Technical Report 3 (2): 108-116. https://doi.org/10.1046/j.1442-8903.2002.00102.x

Bruun, S., Jensen, L.S., Vu, V.T.K. and Sommer, S.G. 2014. Small-scale household biogas digesters: An option for global warming mitigation or a potential climate bomb? Renewable \& Sustainable Energy Reviews 33: 736-741. https://doi.org/10.1016/j.rser.2014.02.033

Chanza, N., Chigona, A., Nyahuye, A., Mataera-Chanza, L., Mundoga, T. and Nondo, N. 2018. Diagnosing barriers to climate change adaptation at community level: Reflections from Silobela, Zimbabwe. GeoJournal 84: 771-783. https://doi.org/10.1007/s10708-018-9890-3

Christensen, G. and Zindi, C. 1991. Patterns of livestock ownership and distribution in Zimbabwe's communal areas; AEE Working Paper no.4. Harare, Mt. Pleasant: AEE.

Coleman, J. 1988. Social capital in the creation of human capital. American Journal of Sociology 94 (Supplement), S95S120. https://doi.org/10.1086/228943

Cornejo, C. and Wilkie, A.C. 2010. Greenhouse gas emissions and biogas potential from livestock in Ecuador. Energy for Sustainable Development 14 (4): 256-266. https://doi.org/10.1016/j.esd.2010.09.008

Cuéllar, A.D. and Webber, M.E. 2008. Cow power: The energy and emissions benefits of converting manure to biogas. Environmental Research Letters 3 (3): Article \# 034002 https://doi.org/10.1088/1748-9326/3/3/034002

Dale, A. and Newman, L. 2010. Social capital: A necessary and sufficient condition for sustainable community development? Community Development Journal 45(1): 5-21. https://doi.org/10.1093/cdj/bsn028

Engbersen, G., Snel, E. and Leerkes, A. 2006. Transitional involvement and social integration. Global Networks, A Journal of Transitional Affairs 6 (3): 285-308. https://doi.org/10.1111/j.1471-0374.2006.00145.x

Field, J. 2008. Social capital. London, UK: Routledge. https://doi.org/10.4324/9780203930519

Foster, K.A., Pitner, R., Freedman, D.A., Bell, B.A. and Shaw, T.C. 2015. Spatial dimensions of social capital. City and Community 14 (4): 392-409. https://doi.org/10.1111/cico.12133

Fukuyama, F. 2001. Social capital, civil society and development. Third World Quarterly 22 (1): 7-20. https://doi.org/10.1080/713701144

Gabisa, E.W. and Gheewala, S.H. 2019. Potential, environmental, and socio-economic assessment of biogas production in Ethiopia: The case of Amhara regional state. Biomass and Bioenergy 122: 446-456. https://doi.org/10.1016/j.biombioe.2019.02.003

Gates, R. and Lee, M. 2005. City of Vancouver. Sustainability Group. Policy Report, Social Development. Available at https://council.vancouver.ca/20050524/documents/p1.pdf.

Grootaert, C. and van Bastelaer, T. 2002. Understanding and measuring social capital: A multidisciplinary tool for practitioners. World Bank, Washington DC. Available at https://openknowledge.worldbank.org/handle/10986/14098. https://doi.org/10.1596/0-8213-5068-4

Hamed, T.A. and Bressler, L. 2019. Energy security in Israel and Jordan: The role of renewable energy sources. Renewable Energy 135: 378-389. https://doi.org/10.1016/j.renene.2018.12.036

Hertel, T.W., Burke, M.B. and Lobell, D.B. 2010. The poverty implications of climate-induced crop yield changes by 2030. Global Environmental Change 20 (4), 577-585. https://doi.org/10.1016/j.gloenvcha.2010.07.001

Indraprahasta, G.S. and Alamsyah, P. 2014. Can household-scale biogas support rural Development? Insight from the study in Cibodas village. Rural Research \& Planning Group (RRPG), $5^{\text {th }}$ International Conference and Field Study in Malaysia, 26-28 August 2014, INFRA Bangi, Malaysia. 
IPCC [Intergovernmental Panel on Climate Change]. 2014. Summary for Policymakers: Climate Change 2014, Mitigation of Climate Change. Contribution of Working Group III to the Fifth Assessment Report of the Intergovernmental Panel on Climate Change. In Edenhofer, O., Pichs-Madruga, R., Sokona, Y., Farahani, E., Kadner, S., Seyboth, K. et al. (eds.). Cambridge, United Kingdom and New York, NY, USA: Cambridge University Press.

Johnson, L. 2016. What is social capital? In Greenberg, A.G., Gullotta, T.P. and Bloom, M. (eds.). Social capital and community well-being. London, UK: Springer: 199-214.

Landi, M., Sovacool, B.K. and Eidsness, J. 2013. Cooking with gas: Policy lessons from Rwanda's National Domestic Biogas Program (NDBP). Energy for Sustainable Development 17: 347-356. https://doi.org/10.1016/j.esd.2013.03.007

Lin, N., Cook, K. and Burt, R.S. 2001. Social capital: Theory and research. New York: Aldine de Gruyter.

Malan, S. 2004. Social assessment of the proposed Le Grand George Golf Estate for the scoping phase of environmental assessment, (Draft 2). Available at https://www.sahra.org.za/sahris/sites/default/files/heritagereports/D3\%20Visual\%20Statement.pdf (accessed 6 June 2020).

Mandelli, S., Barbieri, J., Mereu, R., Colombo, E. 2016. Off-grid systems for rural electrification in developing countries: Definitions, classification and a comprehensive literature review. Renewable and Sustainable Energy Reviews 58: 1621-1646. https://doi.org/10.1016/j.rser.2015.12.338

Marambanyika, T., Beckedahl, H. and Ngetar, N.S. 2016. Community strategies to promote sustainable wetland-based food security in rural areas of Zimbabwe. GeoJournal 82: 987-1003. https://doi.org/10.1007/s10708-016-9724-0

Masama, E. 2016. Research note: Impact of climate change on livestock production in Zimbabwe. International Open and Distance Learning Journal 2 (1): 47-53.

Mohan, B., Chand, M.B., Upadhyay, B.P., and Maskey, R. 2012. Biogas option for mitigating and adaptation of climate change. Rentech Symposium Compendium 1: 5-9.

Mshandete, A.M. and Parawira, W. 2009. Biogas technology research in selected sub-Saharan African countries - A review. African Journal of Biotechnology 8 (2): 116-125.

Mugandani, R., Wuta, M., Makarau, A. and Chipindu, B. 2012. Re-classification of agro-ecological regions of Zimbabwe in conformity with climate variability and change. African Crop Science Journal 20 (s2): 361-369.

Muller, J. and Coetzee, T. 2012. Social capital and socio-economic development in developing political economies. African Journal of Public Affairs 5 (1): 117-131.

Mwirigi, J., Balana, B., Mugisha, J., Walekhwa, P., Melamu, R., Nakami, S. and Makenzi, P. 2014. Socio-economic hurdles to widespread adoption of small-scale biogas digesters in Sub-Saharan Africa: A review. Biomass and Bioenergy XXX: 1-9. https://doi.org/10.1016/j.biombioe.2014.02.018

Palit, D. 2013. Solar energy programs for rural electrification: Experiences and lessons from South Asia. Energy for Sustainable Development 17: 270-279. https://doi.org/10.1016/j.esd.2013.01.002

Pathak, H., Jain, N., Bhatia, A. Mohanty, S. and Gupta, N. 2009. Global warming mitigation potential of biogas plants in India. Environmental Monitoring Assessment 157: 407-418. https://doi.org/10.1007/s10661-008-0545-6

Pilloni, M., Hamed, T.A., Joyce, S. 2020. Assessing the success and failure of biogas units in Israel: Social niches, practices, and transitions among Bedouin villages. Energy Research and Social Science 61: 101328. https://doi.org/10.1016/j.erss.2019.101328

Pretty, J. 2002. People, livelihoods and collective action in biodiversity management. In: O'Riordan, T. and Stoll-Kleeman, S. (eds). Biodiversity, sustainability and human communities: Protecting beyond the protected. Cambridge, UK: Cambridge University Press: 61-86. https://doi.org/10.1017/CB09780511492655.005

Putnam, R. D. 2000. Bowline alone: The collapse and revival of American community. New York, USA: Simon and Schuster.

Putnam, R.D. 1996. Who killed civic America? Prospect 6: 66-72. https://doi.org/10.1145/358916.361990

Reed, L.S., Springer, L.C., Dougill, A.J., Perkins, J.S., Atlhopheng, J.R., Mulale, K. and Favretto, N. 2015. Reorienting land degradation towards sustainable land management: Linking sustainable livelihoods with ecosystem services in rangeland systems. Journal of Environmental Management 151: 472-485. https://doi.org/10.1016/j.jenvman.2014.11.010

Somanathan, E. and Bluffstone, R. 2015. biogas: clean energy access with low-cost mitigation of climate change. Policy Research Working Papers. World Bank. https://doi.org/10.1596/1813-9450-7349

Surroop, D., Bundhoo, Z.M.A and Raghoo, P. 2019. Waste to energy through biogas to improve energy security and to transform Africa's energy landscape. Current Opinion in Green and Sustainable Chemistry 18: 79-83. https://doi.org/10.1016/j.cogsc.2019.02.010

Tavirimirwa, B., Mwembe, R., Ngulube, B., Banana, N.Y.D., Nyamushamba, G.B., Ncube, S. and Nkomboni, D. 2013. Communal cattle production in Zimbabwe: A review. Livestock Research for Rural Development 25: Article \#217 Available at http://www.lrrd.org/lrrd25/12/tavi25217.htm 
Tigabu, A.D, Berkhout, F. and van Beukering, P. 2015. The diffusion of a renewable energy technology and innovation system functioning: Comparing bio-digestion in Kenya and Rwanda. Technological Forecasting and Social Change 90: 331-345.

https://doi.org/10.1016/j.techfore.2013.09.019

Tol, R.S.J. 2005. Adaptation and mitigation: Trade-offs in substance and methods. Environmental Science \& Policy 8: 572-578.

https://doi.org/10.1016/j.envsci.2005.06.011

Uphoff, N. and Wijayaratna, C.M. 2000. Demonstrated benefits from social capital: The productivity of farmer organisations in Gal Oya, Sri Lanka. World Development 28: 1875-1890. https://doi.org/10.1016/S0305750X(00)00063-2

Yadoo, A. and Cruickshank, H. 2012. The role for low carbon electrification technologies in poverty reduction and climate change strategies: A focus on renewable energy mini-grids with case studies in Nepal, Peru and Kenya. Energy Policy 42: 591-602. https://doi.org/10.1016/j.enpol.2011.12.029

Yasmin, N. and Grundmann, P. 2019. Adoption and diffusion of renewable energy - The case of biogas as alternative fuel for cooking in Pakistan. Renewable and Sustainable Energy Reviews 101: 255-264. https://doi.org/10.1016/j.rser.2018.10.011

ZimStat, 2013. Census 2012: Midlands. Harare: Zimbabwe National Statistical Agency (ZimStat). 